\title{
Larval accumulation in the lee of a small headland: implications for the design of marine reserves
}

\author{
Amber J. Mace, Steven G. Morgan* \\ Bodega Marine Laboratory, University of California at Davis, PO Box 247, Bodega Bay, California 94923, USA
}

\begin{abstract}
Oceanic currents and larval accumulation potentially have large impacts on the choice of locations for marine reserves. Larval settlement of benthic invertebrates was greater in the lee than on the windward side of a small headland during the height of upwelling in central California during 2001 and 2002. Strong upwelling during the study was indicated by mean seasonal Bakun indices of 149 to $176 \mathrm{~m}^{3} \mathrm{~s}^{-1}$ per $100 \mathrm{~m}$ of coastline in 2001-2002. Weekly sampling of near-surface and nearbottom settlement in the lee of Bodega Head from August 2000 to September 2001 revealed that most larvae of $7 \mathrm{crab}$ taxa settled during spring and summer, which coincides with the upwelling season. Comparison of sites in the protected (lee) and exposed (windward) sides of the headland (2 sites each) during the peak settlement season in 2001 showed that most larvae settled in the lee of the headland, including $91 \%$ of crabs, $89 \%$ of barnacles, and $80 \%$ of mussels in weekly samples. During 2002, weekly sampling at 1 protected and 1 exposed site also demonstrated that most settlement occurred in the lee of the headland, including $74 \%$ of crabs, $82 \%$ of barnacles, and $65 \%$ of mussels. Crabs settled mostly at the surface, whereas barnacles and mussels primarily settled near the bottom, indicating that postlarvae in both surface and bottom waters accumulate in the lee of the headland. Larval accumulation zones should be included in networks of marine reserves to supply adult populations with propagules in recruitment-limited upwelling regions.
\end{abstract}

KEY WORDS: Larval retention - Larval dispersal · Headland eddy · Recirculation · Marine reserve · Meroplankton

Resale or republication not permitted without written consent of the publisher

\section{INTRODUCTION}

Topographic features of shorelines appear to generate predictable variation in the larval supply to adult populations and communities (Ebert \& Russell 1988). Several studies have observed increased zooplankton abundance and larval settlement in the lee of headlands (Caffey 1985, Murdoch 1989, Gaines \& Bertness 1992, Rankin et al. 1994, Wing et al. 1995b, 1998, Graham \& Largier 1997, Archambault \& Bourget 1999, Lagos et al. 2002). In upwelling regions, larval supply is greater on the leeward side of major headlands, where larvae may be entrained into waters that are retained there (Wing et al. 1995a,b). On the windward side, strong upwelling jets may advect larvae far offshore (Wing et al. 1995a,b). When winds relax, the larvae-rich waters in the lee of the headland may flow poleward around the headland, allowing for settlement of larvae on the poleward side of the headland. Although upwelling generally decreases during the El Niño Southern Oscillation events, settlement along the poleward side of a major headland has been observed to decrease rather than increase, perhaps due to the decline in productivity of the California Current System (Lundquist et al. 2000) or due to the absence of this upwelling-related larval accumulation and poleward transport mechanism.

Previous studies of headlands have generally been on a scale of 10 to $100 \mathrm{~km}$ (Murdoch 1989, Rankin et al. 1994, Graham \& Largier 1997, Wing et al. 1998), except for a recent study around Point Loma in San Diego, California (Roughan et al. 2005b). It is unclear whether this mechanism operates around small headlands, which are much more common and relevant to the 
establishment of marine reserves (no-take zones), which typically are less than $10 \mathrm{~km}$ long. Information on large-scale processes (>100 km) must be coupled with an understanding of processes at a smaller scale $(<10 \mathrm{~km})$ in the nearshore environment in order to design an effective network of marine reserves, which should include areas that export larvae to adjacent reserves as well as areas that are hotspots of larval settlement.

Larvae that accumulate in the lee of small headlands may have been produced there or may have immigrated from elsewhere; we therefore refer to such areas of high larval concentration as accumulation rather than retention zones, which indicate areas where larvae have been locally produced and retained (Warner et al. 2000). Small headlands may allow populations with planktonic larvae to persist by (1) increasing the retention of local larvae nearshore (Roughan et al. 2005a); (2) entraining remotely spawned larvae (Gaylord \& Gaines 2000); and (3) accelerating larval development through elevated concentrations of food and warmer water, thereby reducing the pelagic larval duration and exposure to predation (Pechenik 1987, Sulkin \& McKeen 1994, Forward et al. 2001).

Larval behaviour also plays a role in keeping larvae near parental (and natal) habitats during development or by returning larvae to suitable settlement sites late in development (Morgan 1995, Shanks 1995, Kingsford et al. 2002, Sponaugle et al. 2002). Depth preferences coupled with vertical migrations between opposing stratified currents enable larvae to regulate alongshore and cross-shelf movements (reviewed in Morgan 1995). Onshore transport of late-stage larvae may occur by winds, internal waves, and other physical mechanisms coupled with an ontogenetic shift in depth preference (Shanks 1995). Because multiple mechanisms may return larvae to shallow-water habitats, both interspecific and congeneric differences in the timing of larval settlement to shallow-water habitats may occur, because larvae may exploit multiple onshore delivery mechanisms (Mace \& Morgan in press).

Larval accumulation and retention may be more common than once thought (Morgan 1995, Jones et al. 1999, Cowen et al. 2000, Hughes et al. 2000, Morgan 2001, Swearer et al. 2002), and larval retention rates and onshore settlement pulses have been linked to parental populations (Paris \& Cowen 2004, Jones et al. 2005). This results in a stronger link between stock and recruitment, greater vulnerability to reductions in recruitment from overfishing, greater possibility for local adaptation, and greater local benefit from marine reserves (Strathmann et al. 2002). Larval retention and cross-shelf migrations between adult habitats and larval nursery areas are critical to the success of a widespread reproductive strategy that involves the devel- opment of weakly swimming microscopic larvae in upwelling regions of a dynamic ocean (Roy 1998).

Evidence for larval accumulation in the lee of headlands comes primarily from studies that observe the spatial distribution of settlement or recruitment of marine invertebrates such as crabs, barnacles, and urchins around headlands (Ebert \& Russell 1988, Wing et al. 1995a, Lagos et al. 2002). Therefore, to test the effect of coastal topographical features on larval supply, we investigated settlement of postlarvae around Bodega Head, a small headland in a strong upwelling region, for 2 yr. Here we use settlement abundance as a proxy for relative larval supply among the sites monitored (Gaines et al. 1985, Minchinton \& Scheibling 1991, Miron et al. 1995). In a concurrent study we found that cyclonic recirculation in Bodega Bay at depth provides a potential mechanism for retaining larvae and accumulating postlarvae (Roughan et al. 2005a). Cyclonic recirculation was strongest during upwelling due to the increased equatorward alongshore flow past Bodega Head. Recirculation weakens during relaxation or downwelling, potentially exporting larvae north of the headland. In a second concurrent study settlement of postlarvae in surface waters in the lee of the headland was sampled bi-daily (every 2d)to assess temporal settlement patterns and potential delivery mechanisms (Mace \& Morgan in press). In the current study we sampled over longer time periods to assess horizontal and vertical patterns of larval settlement around a small headland. The objectives of the present study were to determine (1) the strength of upwelling compared to previous years; (2) seasonal patterns of larval settlement by benthic invertebrates; (3) settlement at exposed and protected sites around the headland; and (4) the synchrony of larval supply to exposed and protected sites. We also draw inferences for the design of marine reserves.

\section{MATERIALS AND METHODS}

Study area. The study was conducted around Bodega Head $\left(\mathrm{BH}, 38^{\circ} 18^{\prime} \mathrm{N}, 123^{\circ} 04^{\prime} \mathrm{W}\right)$ in central California, which is characterized by persistent equatorward winds during spring and summer (Fig. 1). Bodega Bay occurs on the leeward side of this small headland and is a shallow, broad, southwest-facing embayment. The bay mouth is approximately $11 \mathrm{~km}$ wide from the northern tip at $\mathrm{BH}$ to the southern tip at Tomales Point, expanding to $15 \mathrm{~km}$ wide landward of the mouth, and it is approximately $3.5 \mathrm{~km}$ from mouth to shore. The rocky outcrops of $\mathrm{BH}$ and Tomales Point continue as a shallow ( $<15 \mathrm{~m}$ deep) submarine ridge across the mouth of the bay (Fig. 1). The ridge rises to the surface to form Bodega Rocks toward the northern 
end of the bay. The bay is 20 to $25 \mathrm{~m}$ deep, and depths steeply increase to more than $40 \mathrm{~m}$ seaward of the ridge. Tides are mixed semi-diurnal, with a tidal range of 1.2 to $2.9 \mathrm{~m}$. A detailed study of currents in the area is available in Roughan et al. (2005a).

Upwelling. Offshore wind speed and direction were obtained from the National Data Buoy Center (NDBC 46013, 38 $13^{\prime} 30^{\prime \prime} \mathrm{N}, 123^{\circ} 19^{\prime} 00^{\prime \prime} \mathrm{W}$; http://www.ndbc. noaa.gov) and local wind velocities were obtained from a land-based site at Bodega Marine Laboratory (BML, 38 19'03.35" N, 12304' 17.20" W; http://bml. ucdavis.edu/boon). Alongshore winds at BML and the NDBC buoy were correlated to $95 \%$ confidence with $\mathrm{r}=0.88$ and a lag of $2 \mathrm{~h}$ (BML leads NDBC) (Roughan et al. 2005a). Wind data from the offshore buoy were used because they are more representative of largerscale wind-forcing events. Alongshore wind stress was calculated (Large \& Pond 1981) from 10 min-averaged data that were adjusted to a height of $10 \mathrm{~m}$ above sea level using a neutral-stability wind profile and rotated to a principal axis of $317^{\circ} \mathrm{T}$ (true north). Negative values indicate equatorward wind stress, and larger negative values reflect stronger upwelling-favourable winds. Low or positive values are associated with relaxation or downwelling conditions.
Upwelling indices (from $39^{\circ} \mathrm{N}, 125^{\circ} \mathrm{W}$ ) were obtained from the National Oceanographic and Atmospheric Administration's Pacific Fisheries Environmental Laboratory (PFEL), Pacific Grove, California (http:// www.pfeg.noaa.gov). Positive values indicate upwelling and offshore transport of surface waters resulting from equatorward wind stress, and low values indicate relaxation of upwelling. Negative values indicate downwelling and the onshore advection of surface waters due to poleward wind stress. Averages of mean daily values of upwelling indices for 30 April to 13 August (sampling period from Lundquist et al. 2000) between 1995 and 2004 were compared with those obtained during 2001-2002.

Daily averages of temperature were obtained from 2 Optic StowAway TidbiT ${ }^{\circledR}$ thermistors, which were attached to a settlement mooring at each site. On each mooring, thermistors were placed $1 \mathrm{~m}$ off the bottom (approx. $9 \mathrm{~m}$ deep) and $1 \mathrm{~m}$ below the surface. Temperature $\left( \pm 0.2^{\circ} \mathrm{C}\right)$ was recorded every $6 \mathrm{~min}$. Daily averages of salinity $( \pm 0.005 \mathrm{psu})$ were obtained from a Sea-Bird Electronics thermosalinograph (SBE 45 MicroTSG) that was situated in the seawater intake line at BML's BOON (Bodega Ocean Observing Node). The correlation between alongshore wind stress and temperature was calculated to determine whether there was an upwelling response to wind variability, and the correlation between local temperature and salinity was calculated to determine the local response to changes in wind conditions.

Larval settlement. Larval settlement by benthic invertebrates was monitored year-round (August 2000 to September 2001) at the Jetty site (JT) to assess how settlement varied through the year (Fig. 1). During 2001 and 2002, larval settlement was monitored weekly around $\mathrm{BH} 1 \mathrm{~m}$ below the surface and $1 \mathrm{~m}$ above the bottom during the peak settlement season, which was determined during the first year of the study to extend from April to September (see also Wing et al. 1995b, 2003, Lundquist et al. 2000). During 2001, settlement was monitored at 2 sites on the windward (exposed) side of the headland at $\mathrm{BML}$ and $\mathrm{BH}$, and at 2 sites in the lee (protected) side of the headland at JT and Pinnacle Rock (PR) (Fig. 1). Three of these sites (BML, JT, $\mathrm{PR}$ ) were situated adjacent to onshore long-term monitoring of rocky intertidal communities (indicated by stars in Fig. 1) by the Gulf of the Farallones
Fig. 1. Exposed and protected sampling sites. All 4 sites (BH: Bodega Head; BML: Bodega Marine Laboratory; JT: Jetty site; PR: Pinnacle Rock) were sampled in 2001. Only BML and PR were sampled in 2002. Arrows indicate simplified flow around Bodega Head 
National Marine Sanctuary or BML. Larval settlement has been monitored at the BML site since 1992 (Wing et al. 1995a,b, 2003, Lundquist et al. 2000). During 2002, only 1 exposed (BML) and 1 protected site (PR) were sampled.

Each site consisted of an array of 3 moorings with attached collectors spaced approximately $50 \mathrm{~m}$ apart along the $10 \mathrm{~m}$ isobath. For comparison among sites, collectors were placed at similar depths $(10 \mathrm{~m})$ and habitats (sandy substrate adjacent to submerged rocks). Settlement substrate for crabs, mussels, and echinoderms consisted of two $10 \times 30 \mathrm{~cm}$ mesh bags each containing 3 Tuffy $^{\circledR}$, kitchen scrub pads. Artificial settlement substrate for barnacles was a $10 \times 10 \mathrm{~cm}$ polyvinylchloride plate covered on both sides with black $3 \mathrm{M}^{\circledR}$, safety walk tape. Collectors were rinsed in fresh water, and settlers were fixed in $50 \%$ ethanol. Postlarvae and juveniles were identified to species when possible using available keys (Lough 1974, Shanks 2001). Cancer productus and Cancer antennarius were distinguished as juveniles but not as postlarvae. These species were collectively called $C$. antennarius/productus, even though $79 \%$ of the juveniles were C. antennarius. Similarly, Pugettia producta and Pugettia richii were not distinguished at the postlarval stage, although $95 \%$ of the juveniles collected were identified as P. producta. Sea stars (Pisaster spp. and Leptasterias spp.), urchins (Stronglyocentrotus franciscanus and Stronglyocentrotus purpuratus), and barnacles were combined (except Lepas spp.) due to difficulty of correctly identifying new recruits.

Data analysis. Because protected and exposed sites may be influenced by mesoscale oceanographic features, they may be environmentally correlated and would not meet the primary assumption of standard parametric analysis: independent replicates. Thus randomization tests were used to determine whether settler abundance differed between exposure (sites), settlement depth, and year. A distribution of F-ratios was generated via parametric bootstrapping and used to test whether the observed differences were statistically significant. Random samples of $1000 \log _{10}$-transformed abundance of settlers were drawn, with replacement, to generate a distribution of F-ratios and p-values. A factorial model was used considering site (protected vs. exposed), year (2001 vs. 2002), depth (surface vs. bottom), and all interactions. Because 2 sites (BML and PR) were monitored in 2002, only these 2 sites of the 4 sites from 2001 were included in the analysis.

To determine whether settlers arrived at the same time on each side of the headland during 2001 and 2002, the abundance of settlers at a protected site (PR) were correlated with those at an exposed site (BML) $(n=129)$. A positive relationship would indicate that $a$ mesoscale oceanographic feature consistently deliv- ered larvae to exposed and protected sites in similar numbers, whereas a negative relationship would indicate that while one site received larvae under a specific condition the other site received larvae only under other conditions. Alternatively, no relationship would be found if larval retention or accumulation resulted in settlement in the lee of the headland independent of settlement at the exposed site.

\section{RESULTS}

\section{Upwelling}

Characteristic upwelling winds with brief periods of weaker wind occurred during the spring and summer, and the strength and duration of these cycles varied between years. Upwelling was strong during 2001-2002 and was strongest in 2002 (Fig. 2). The average upwelling index $\left(\mathrm{m}^{3} \mathrm{~s}^{-1}\right.$ per $100 \mathrm{~m}$ coastline) for 2001 and 2002 was $149 \pm 9$, and $176 \pm 11$ SE respectively. Long periods of upwelling were punctuated by brief periods of relaxation (Fig. 3). One upwelling event in 2001 lasted more than a month (late May to late June). When equatorward alongshore wind stress increased (larger negative values), temperature decreased and salinity typically increased, indicating the arrival of newly upwelled water, though the response was not as pronounced for salinity. Hence, there was an inverse relationship between wind stress and temperature and a positive relationship between wind stress and salinity. There was little interannual variation in the response of temperature and salinity to wind stress, as indicated by the similar high correlation values for 2001 and 2002 (Table 1).

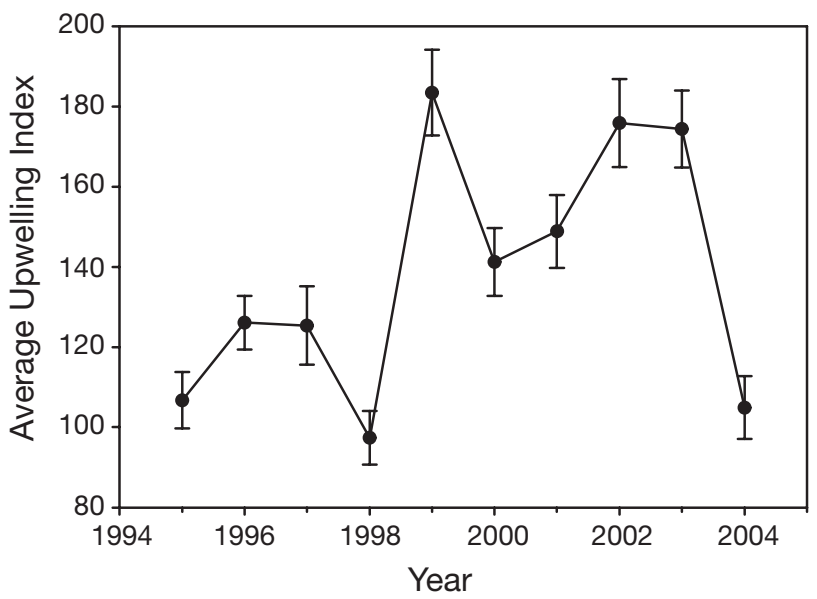

Fig. 2. Bakun upwelling index from 1995 to 2004, showing mean of daily values $\pm 1 \mathrm{SE}$ for the upwelling season (30 April to 13 August) from $39^{\circ} \mathrm{N}$ latitude 


\section{Larval settlement}

Sampling at JT from August 1, 2000 to August 31, 2001 revealed that more larvae settled during spring and summer than during fall and winter (Fig. 4). During this year, $88 \%$ of crabs settled between May and August. Cancrids, porcellanids, and majids were most abundant, followed by small numbers of grapsids and pagurids. The 3 most abundant taxa settled throughout much of the year. However, cancrids were most abundant from January to July, with a peak in May and June; porcellanids peaked in July and August; and majids were most abundant between May and August, with a peak in June. No crabs settled during August 2000.

Twenty-one meroplankton taxa, including species of crabs, barnacles, mussels, and urchins, settled dur- ing the upwelling season in 2001 and 2002 (Table 2). Of the 9 most abundant taxa, settlement at the protected sites (PR, JT) was higher than at the exposed sites (BML, BH) during 2001; $91 \%$ of 9722 crabs settled

Table 1. Correlations between mean daily alongshore wind stress (negative values indicate increasing equatorward wind stress) rotated to $317^{\circ}$, surface temperature from Bodega Marine Laboratory (BML) and Pinnacle Rock (PR), and salinity measured at BML's BOON (Bodega Ocean Observing Node). All values are significant at $\mathrm{p}=0.05$

\begin{tabular}{|cccccc}
\hline Year & $\begin{array}{c}\text { Wind } \\
\text { stress vs } \\
\text { BML temp. }\end{array}$ & $\begin{array}{c}\text { Wind } \\
\text { stress vs } \\
\text { PR temp. }\end{array}$ & $\begin{array}{c}\text { Wind } \\
\text { stress vs } \\
\text { salinity }\end{array}$ & $\begin{array}{c}\text { BML } \\
\text { temp. vs } \\
\text { salinity }\end{array}$ & $\begin{array}{c}\text { PR } \\
\text { temp. vs } \\
\text { salinity }\end{array}$ \\
\hline 2001 & 0.6551 & 0.6036 & -0.4081 & -0.6502 & -0.2338 \\
2002 & 0.663 & 0.6904 & -0.4666 & -0.8088 & -0.7775 \\
\hline
\end{tabular}

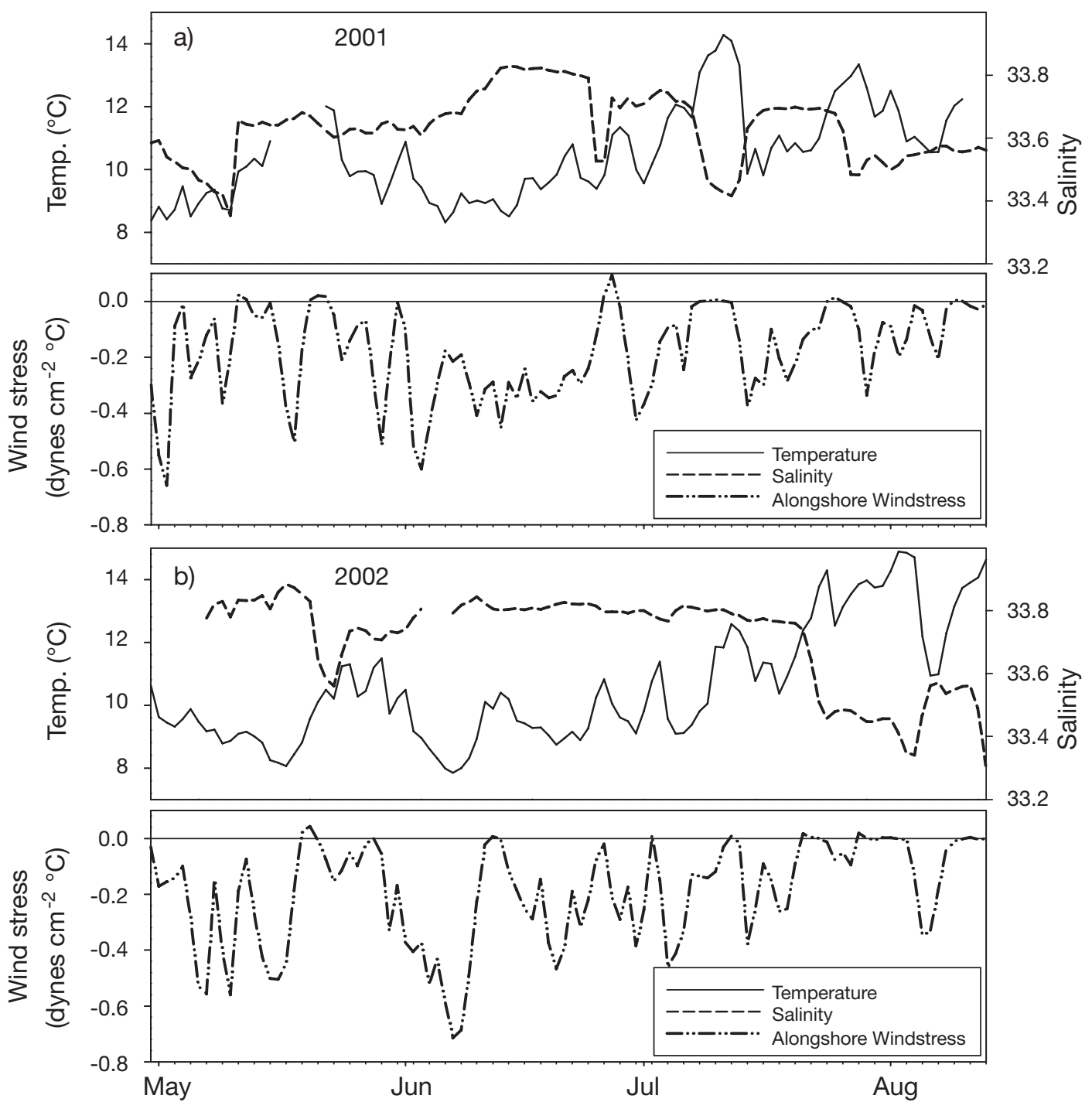

Fig. 3. (a) 2001 and (b) 2002 time series at BML of daily averages of temperature, salinity and alongshore wind stress rotated to $317^{\circ}$ (negative values indicate increasing equatorward wind stress) 


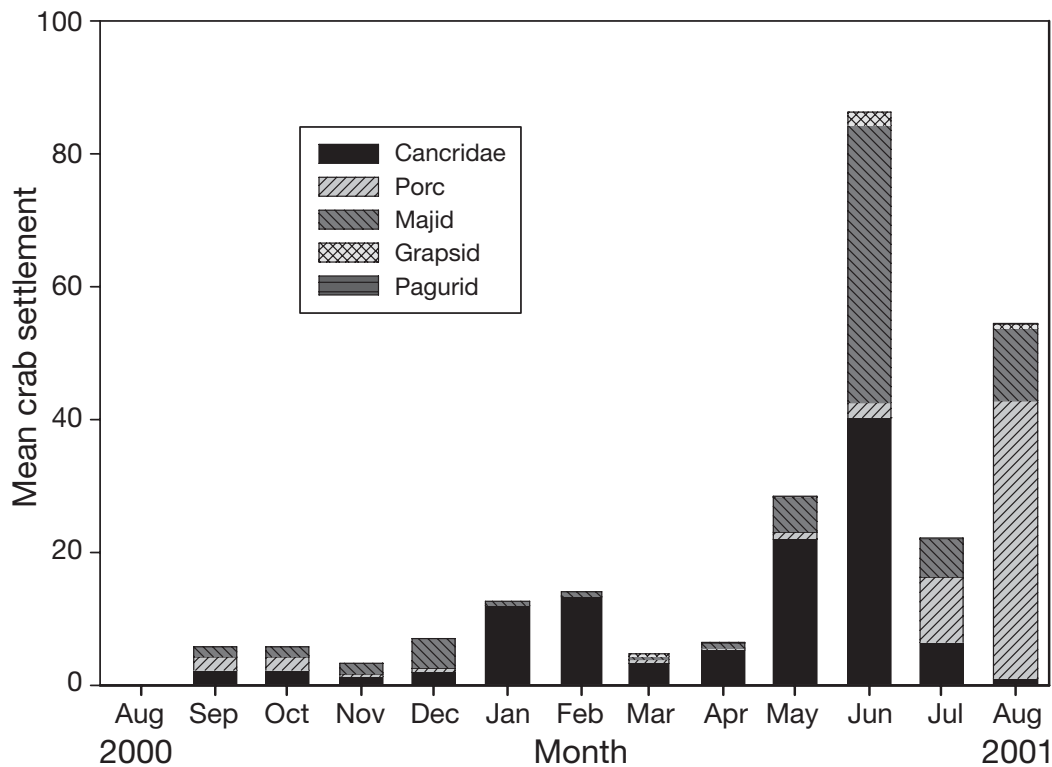

Fig. 4. Stacked mean monthly settlement of 5 crab families-Cancridae, Porcellanidae, Majidae, Grapsidae and Paguridae - at JT from August 2000 to August 2001

in the lee of Bodega Head, including $98 \%$ of porcellanids, $86 \%$ of cancrids, $85 \%$ of grapsids, $71 \%$ of majids, and $57 \%$ of pagurids (Fig. 5). Furthermore, $89 \%$ of Balanus spp. and $80 \%$ of Mytilus spp. also settled in the protected region in the lee of the headland. While overall settlement was higher at protected

Table 2. Number of settlers collected in 2001 and 2002 and percent settlement for crab species

\begin{tabular}{|lrr|}
\hline & Total & $\%$ \\
\hline Crabs & 16020 & \\
Petrolisthes cinctipes & 8932 & 55.8 \\
Cancer antennarius/productus & 3387 & 21.1 \\
Pugettia producta/richii & 2100 & 13.1 \\
Cancer magister & 753 & 4.7 \\
Petrolisthes eriomerus & 406 & 2.5 \\
Hemigrapsus nudus & 199 & 1.2 \\
Pagurus spp. & 196 & 1.2 \\
Fabia subquadrata & 3 & $<1.0$ \\
Loxoryncus spp. & 2 & $<1.0$ \\
Petrolisthes manimaculus & 20 & $<1.0$ \\
Pachygrapsus crassipes & 16 & $<1.0$ \\
Pachycheles pubescens & 4 & $<1.0$ \\
Barnacles & & \\
Balanus spp. & 81565 & \\
Lepas spp. & 176 & \\
Mussels & & \\
Mytilus spp. & 8470 & \\
Urchin & & \\
Strongylocentrotus spp. & 24 & \\
Sea star & & \\
Pisaster spp./Leptasterias spp. & 277 & \\
& & \\
\hline
\end{tabular}

sites for most taxa, the species composition varied between protected and exposed sites, with a higher proportion of majids settling at exposed sites and a higher proportion of porcellanids settling at protected sites (Fig. 5). Higher settlement at the protected site again was apparent for most taxa during 2002, although some differences between depth distributions at protected and exposed sites were found (Table 3). More Cancer antennarius/productus, Petrolisthes cinctipes, Petrolisthes eriomerus/manimaculus, Hemigrapsus nudus, Mytilus spp. and Balanus spp. settled in the lee of $\mathrm{BH}$ than along the exposed coast (Fig. 6, Table 3). These species comprised $78 \%$ of the crab settlement in 2001 and $74 \%$ in 2002. Settlement of C. magister, Pagurus spp., and Pugettia producta/richii was similar at exposed and protected sites during 2001 and 2002 (Fig. 6, Table 3). The abundance of settlers was similar between years for 6 taxa; however, more Pagurus spp., Mytilus spp. and Balanus spp. settled in 2002 (Fig. 6, Table 3).

Vertical stratification of settlers differed among and within taxonomic groups. Crabs predominately settled near the surface (Cancer magister, Pagurus spp., Petrolisthes cinctipes, Hemigrapsus nudus, Pugettia producta/richii), but there was no statistical difference between depths for Cancer antennarius/productus and Petrolisthes eriomerus/manimaculus (Fig. 6, Table 3). More P. producta/richii and Pagurus spp. settled at the surface in years of high abundance. In contrast to most crabs, Mytilus spp. and Balanus spp. consistently settled at much higher densities near the bottom.

The strongest positive relationship between the abundances of settlers at exposed and protected sites during 2001 and 2002 combined was obtained for Cancer magister, Pugettia producta/richii, Pagurus spp. and Mytilus spp., suggesting that these taxa may sometimes arrive at both sites at the same time (Table 4 ). The other 5 taxa showed a very weak relationship, and all of them settled more abundantly in the lee of the headland.

\section{DISCUSSION}

\section{Larval accumulation in the lee of headlands}

Most larvae settled in the lee of $\mathrm{BH}$ during both years in which spatial patterns were investigated. Similar patterns have been observed around larger headlands 


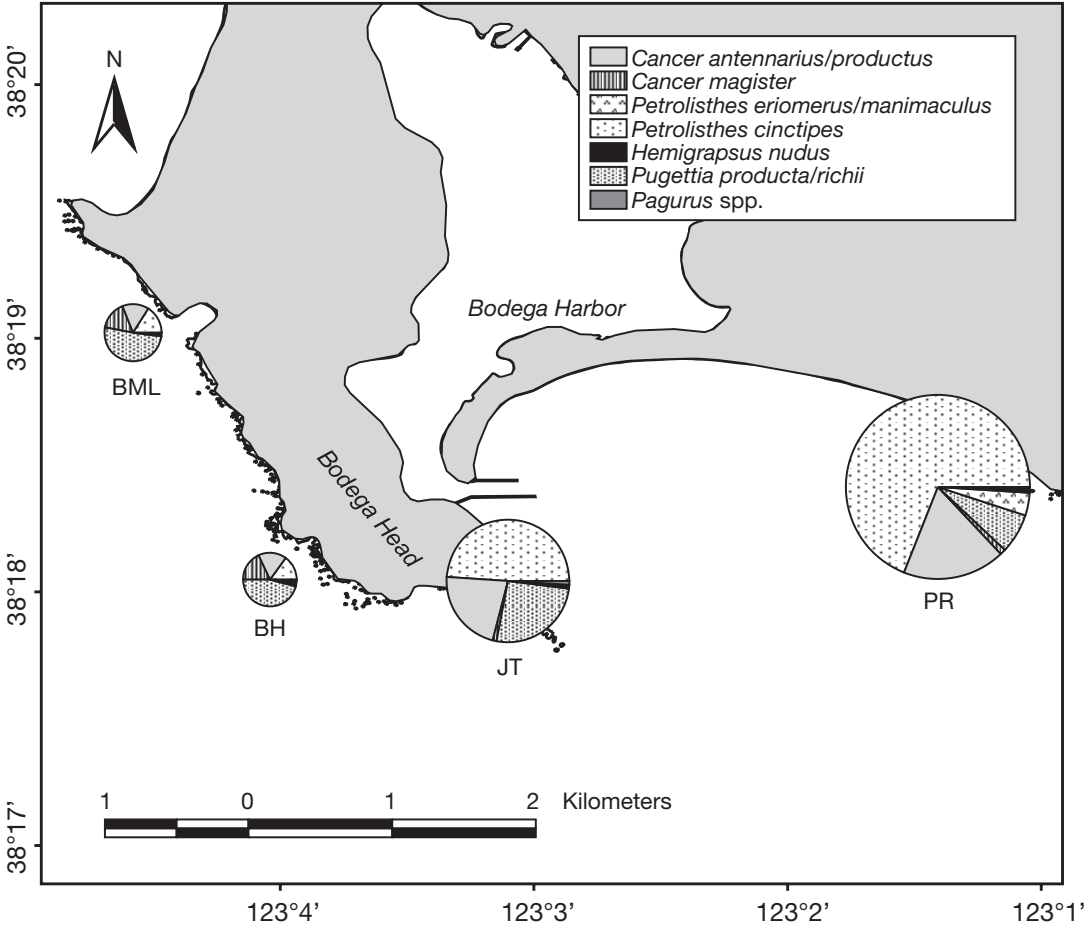

Fig. 5. Mean crab settlement from April to August 2001 at 4 sites around Bodega Head, 2 protected (JT and PR) and 2 exposed (BML and BH)

port of surface waters in the bay, but recirculation of bottom waters did occur at depth, below the direct effect of the wind (Roughan et al. 2005a). This recirculation feature increased with increased upwelling (Graham \& Largier 1997, Penven et al. 2000, Roughan et al. 2005a). Consequently, larvae that remained deep in the water column, or that vertically migrated between northward-flowing surface waters and southward-flowing bottom waters, may remain in the bay during upwelling conditions. Roughan et al. (2005a) explored particle displacement during upwelling using water velocities observed at two of our settlement sites inside (PR) and outside (BML) of the bay and found that larvae undertaking diel vertical migrations would experience nearzero alongshore advection in the bay, while those at BML would be transported approximately $12 \mathrm{~km}$ alongshore over a $3 \mathrm{~d}$ period despite diel vertical migrations (Roughan et al. 2005a). Species of crab larvae collected during our study are known to

around the world (Murdoch 1989, Wing et al. 1995a,b, Graham \& Largier 1997), but this is the first evidence that accumulation zone may occur in the lee of a small headland in an upwelling region. In upwelling regions, upwelling shadows form in the lee of large headlands and are characterized by reduced local wind forcing, localized reversal of alongshore flow, and warm surface waters (Graham \& Largier 1997). A variation of a typical upwelling shadow was seen in Bodega Bay (Roughan et al. 2005a). Upwelling-favourable winds were not sufficiently diminished by the low-lying headland to preclude upwelling and alongshore transundertake diel vertical migrations (Wing et al. 1998), which likely contributed to their accumulation and high settlement inside the bay.

Although the recirculation of bottom waters during upwelling may be the most likely mechanism responsible for the high settlement observed in the lee of $\mathrm{BH}$, other explanations may be postulated. Though these alternative explanations cannot be evaluated, they are unlikely to yield such clear results. These include (1) reduced velocities observed in the bay; (2) wind or tidally generated fronts that may occur at the mouth of the bay which reduce exchange between bay and

Table 3. Randomization results comparing exposure (protected [PR] and exposed [BML]), depth (surface and bottom), and year (2001 and 2002) with mean weekly settlement. p-values are based on the probability that the data are different from randomized data. Values in bold are significant at $\mathrm{p}=0.05$

\begin{tabular}{|lccccccc|}
\hline & Exposure $(E)$ & Depth $(Z)$ & Year $(Y)$ & $Y \times Z$ & $E \times Z$ & $Y \times E$ & $Y \times E \times Z$ \\
\hline Cancer magister & 0.35 & $<\mathbf{0 . 0 0 1}$ & 0.09 & 0.35 & 0.67 & 0.61 & 0.85 \\
Cancer antennarius/productus & $<\mathbf{0 . 0 0 1}$ & 0.22 & 0.12 & 0.32 & 0.38 & 0.06 & 0.58 \\
Petrolisthes cinctipes & $\mathbf{0 . 0 0 1}$ & $<\mathbf{0 . 0 0 1}$ & 0.66 & 0.85 & $\mathbf{0 . 0 1}$ & 0.27 & 0.36 \\
Petrolisthes eriomerus/manimaculus & $\mathbf{< . 0 0 1}$ & 0.11 & 0.99 & 0.99 & $\mathbf{0 . 0 4}$ & 0.43 & 0.72 \\
Hemigrapsus nudus & $\mathbf{0 . 0 0 1}$ & $<\mathbf{0 . 0 0 1}$ & 0.14 & 0.09 & $\mathbf{0 . 0 0 1}$ & 0.98 & 0.68 \\
Pagurus spp. & 0.7 & $\mathbf{0 . 0 0 1}$ & $\mathbf{0 . 0 1}$ & $\mathbf{0 . 0 3}$ & 0.85 & 0.95 & 0.98 \\
Pugettia producta/richii & 0.94 & $\mathbf{< . 0 0 1}$ & 0.14 & $<\mathbf{0 . 0 0 1}$ & 0.37 & 0.42 & 0.86 \\
Mytilus spp. & $\mathbf{0 . 0 1}$ & $\mathbf{< . 0 0 1}$ & $\mathbf{0 . 0 0 1}$ & 0.96 & $\mathbf{0 . 0 1}$ & 0.75 & 0.78 \\
Balanus spp. & $\mathbf{0 . 0 0 4}$ & $\mathbf{< . 0 0 1}$ & $\mathbf{0 . 0 2}$ & 0.42 & $\mathbf{0 . 0 4}$ & 0.72 & 0.3 \\
\hline
\end{tabular}



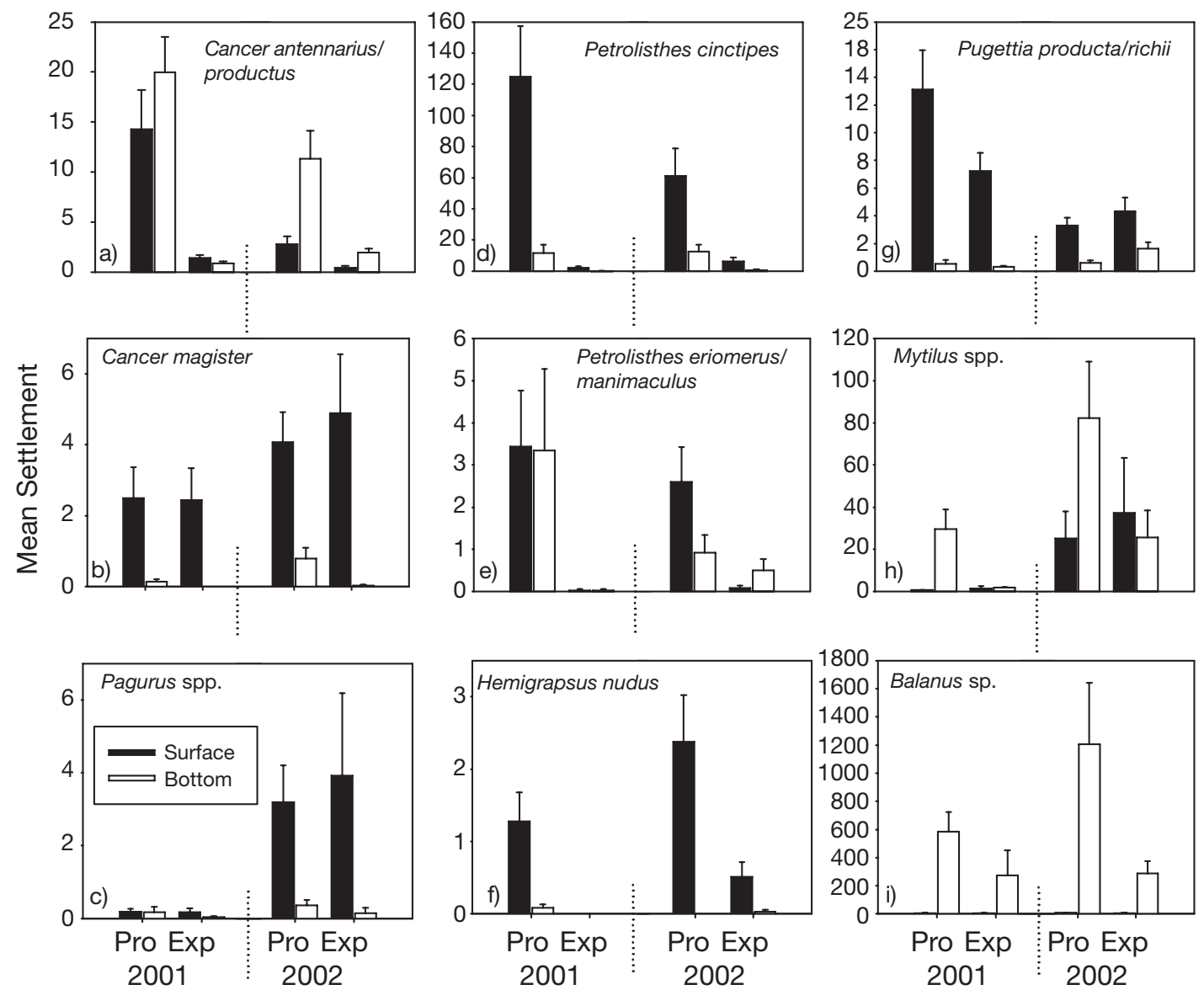

Fig. 6. (a) Cancer antennarius/productus, (b) Cancer magister, (c) Pagurus spp., (d) Petrolisthes cinctipes, (e) Petrolisthes eriomerus/manimaculus, (f) Hemigrapsus nudus, (g) Pugettia producta/richii, (h) Mytilus spp. and (i) Balanus spp. mean settlement $\pm 1 \mathrm{SE}$ compared with exposure (protected [PR] and exposed [BML]), depth (surface and bottom) and year (April to August 2001 and 2002)

Table 4. Correlation values for comparison of timing of settlement at PR and BML for 2001 and 2002 from weekly values $(n=129)$. Values in bold are significant at $p=0.05$

\begin{tabular}{|lcc|}
\hline & BML vs. PR & $\mathrm{p}$ \\
\hline Pagurus spp. & 0.60 & $<\mathbf{0 . 0 0 1}$ \\
Pugettia producta/richii & 0.57 & $<\mathbf{0 . 0 0 1}$ \\
Cancer magister & 0.51 & $<\mathbf{0 . 0 0 1}$ \\
Cancer antennarius/productus & 0.17 & $\mathbf{0 . 0 5}$ \\
Petrolisthes cinctipes & 0.35 & $<\mathbf{0 . 0 0 1}$ \\
Petrolisthes eriomerus/manimaculus & 0 & 0.99 \\
Hemigrapsus nudus & 0.27 & $\mathbf{0 . 0 0 2}$ \\
Mytilus spp. & 0.50 & $<\mathbf{0 . 0 0 1}$ \\
Balanus spp. & 0.37 & $<\mathbf{0 . 0 0 1}$ \\
\hline
\end{tabular}

oceanic water; (3) greater transport into the bay due to non-linear internal waves either because of stratification in the bay or because of internal wave generation over the ridge at the mouth of the bay; and (4) greater availability of rocky substrate outside the bay causing larvae to bypass collectors in favour of more suitable settlement sites nearby. Although fronts at the mouth of the bay may concentrate larvae and enhance residence time in the bay (Rankin et al. 1994), observations are anecdotal and fronts are likely to be transient. The observed recirculation of bottom waters would be more effective and reliable at retaining larvae at the consistently high levels found during this study. Furthermore, internal waves are more active during relaxation conditions (Rosenfeld 1990), but larvae of most species settled in the bay in high abundances during both upwelling and relaxation (Mace \& Morgan in press). Differences in habitat availability inside and outside of the bay are also an unlikely explanation for higher settlement inside the bay, because all collectors were moored in sand next to a rocky shore.

The observed vertical distributions of postlarvae varied among species, but were fairly consistent within species, indicating that postlarvae of each species regulated their position in the water column. Most species of crabs settled at the surface, and at least some of these species are known to be transported onshore in 
surface waters (Shanks 1985). In Roughan et al. (2005a), the vertical distributions of settlers was maintained during upwelling conditions even when the water column was well mixed; $85 \%$ of crab postlarvae settled at the surface during upwelling, and $84 \%$ settled at the surface during downwelling. In contrast, barnacles and mussels settled in higher abundance near the bottom, indicating that they are transported onshore or settle in preferred habitats deeper in the water column (Grosberg 1982, Miron et al. 1995, Pineda \& Caswell 1997, Miron et al. 1999). Thus larvae clearly enter the bay at all depths. Once inside the bay, larvae that occur in bottom waters may remain in the subsurface recirculation feature, whereas surface dwellers are retained by undertaking diel vertical migrations between recirculating bottom waters and southward flowing surface currents (Roughan et al. 2005a). Consequently, both larval behaviour and oceanographic processes are important factors in explaining the observed settlement patterns.

Settlement at exposed and protected sites was best correlated for Pugettia producta/richii, Pagurus spp., Cancer magister, and Mytilus spp., suggesting that larvae may be delivered to the nearshore environment by a single large-scale oceanographic event; however, the weekly sampling interval prevented resolution of potential mechanisms. For example, Wing et al. (1995a) showed that larvae accumulated in the lee of Point Reyes during upwelling and were advected northward to Bodega Bay during relaxation periods. In a companion study, we assessed temporal settlement patterns in Bodega Bay in 2002 and observed that C. magister settlement was positively correlated with relaxation-favourable conditions (Mace \& Morgan in press). This may account for the fairly synchronous settlement of $C$. magister at our study sites, although the timing of arrival for the other 3 taxa was inconclusive. The latter 3 taxa settled in similar numbers at exposed and protected sites high in the water column, whereas Mytilus spp. primarily settled in the lee of the headland low in the water column, suggesting that Mytilus spp. may have been more likely to become entrained in the bay at depth.

A poor relationship between settlement at exposed and protected sites was found for the remaining 5 taxa. All 5 taxa primarily settled in the lee of the headland, suggesting that they were entrained by a combination of behaviour and the subsurface recirculation feature that is strongest in the bay during upwelling events. It is likely that both large- and small-scale oceanographic processes operate to varying degrees throughout the season and their effects on settlement are modulated by availability of competent larvae in the plankton, because settlement was only weakly synchronous for some taxa.

\section{Temporal variation in larval accumulation}

It is well known that there is variation in larval settlement by benthic invertebrates in the Bodega Bay region during April through August (Lundquist et al. 2000, Wing et al. 2003), but little is known about settlement throughout the remainder of the year (Strathmann 1987). We found that most crab species in this study settled in Bodega Bay throughout much of the year, with peaks occurring from May through August. It is counterintuitive that larvae of shallow-water benthic invertebrates develop during the upwelling season (April to August), when offshore transport is most likely to occur (Parrish et al. 1981), because larvae must return to shore to replenish adult populations. Larval entrainment in the lee of both small and large headlands is most effective during upwelling (Graham \& Largier 1997, Wing et al. 1998, Roughan et al. 2005a) and may facilitate larval settlement at many sites along the coast, especially during strong upwelling years. During our study, larvae accumulated in the lee of $\mathrm{BH}$ during 2 strong upwelling years, and larvae of 3 taxa (Pagurus spp., Mytilus spp., Balanus spp.) settled more during the year of strongest upwelling. Moreover, an $8 \mathrm{yr}$ record of larval settlement at the BML site leading up to our study demonstrated that settlement increased during upwelling years, except in 1999, an exceptionally strong upwelling (La Niña) year that followed a strong El Niño year (Lundquist et al. 2000, Wing et al. 2003). However, the average upwelling index in 1999 was also similar to that recorded in 2002 (Fig. 2), when higher larval settlement occurred in the lee of the headland than at this exposed site.

\section{Implications for the design of marine reserves}

Our study demonstrated that larvae accumulated in the lee of a small headland, increasing larval settlement during the height of the upwelling season in 2 consecutive years of strong upwelling. However, these patterns were not observed for all species. Postlarvae were likely to be entrained in recirculating bottom waters and may be exported to adjacent areas along the exposed coast during relaxation events. Postlarvae that are delivered during relaxation events, when the recirculation feature is not as well developed, may not be entrained in the bay. This may explain the patterns observed for Cancer magister, which previously has been shown to settle during relaxation events (Wing et al. 2003, Mace \& Morgan in press).

The recirculation of bottom waters may have been facilitated by a submarine ridge that extends across the mouth of the bay, adding to the growing number 
of ways that accumulation zones may form in the lee of headlands. In addition to surface recirculation observed in upwelling shadows forming in the lee of large headlands, sub-surface recirculation cells may form behind small or low-lying headlands. Further investigations are needed to identify other topographic features of coastlines that facilitate the accumulation of planktonic organisms. Meanwhile, we suggest that both small and large headlands predictably accumulate larvae and are particularly effective during periods of strong upwelling.

While accumulation zones may provide a more reliable source of propagules to adult populations, they may not contain suitable habitat for conserving species or communities of interest. The leeward sides of headlands not only accumulate larvae, but are deposition zones that favour soft-bottom communities. Larvae of hard-bottom species may settle densely on available rocky habitat or disperse to adjacent exposed coasts during relaxation events.

Currently, discussion of the relevance of larvae in reserve design primarily involves the spacing of reserves based on dispersal distances and the seeding of surrounding areas (Largier 2003, Shanks et al. 2003). Incorporating potential accumulation zones into the design of reserve networks in recruitment limited regions with intense upwelling is important because (1) these areas are replenished by abundant settlers and (2) larval dispersal from accumulation zones to adjacent areas is likely during relaxation events. These settlers supply recruits to nearby adult populations as well as a consistent food supply to higher trophic levels. Thus, the spatial predictability of larval accumulation zones and habitat types may be used to inform the establishment of a network of marine reserves in upwelling regions.

Acknowledgements. This manuscript was improved through the expert help of J. Fisher, M. Holyoak, C. Lundquist, J. Largier, T. Grosholz, L. Botsford, J. Castilla and 2 anonymous reviewers. B. Miner provided invaluable help with statistics, J. Fisher with figures and M. Roughan with physical data. We thank the numerous people who contributed countless hours to data collection and sample sorting, including S. McAfee, M. Carver, L. Akins, S. Jørgensen, T. Westman, V. Metcalf, J. Holbrook, M. Buckhorn, A. Haring, M. Donahue, J. Barlow, D. Baum and D. Kaplan. We thank Bodega Marine Laboratory Marine Operations and the Gulf of the Farallones and Cordell Bank National Marine Sanctuaries for their logistical support. This work was funded by Sea Grant \#NA06RG0142 in collaboration with Loo Botsford and Jim Wilen, Lerner-Gray American Museum of Natural History, University of California Natural Reserve System, University of California Davis Graduate Group in Ecology, Golden West Women Flyfishers Foundation and Challenges to California's Natural Resources. It is contribution number 2297 of the Bodega Marine Laboratory.

\section{LITERATURE CITED}

Archambault P, Bourget E (1999) Influence of shoreline configuration on spatial variation of meroplanktonic larvae, recruitment and diversity of benthic subtidal communities. J Exp Mar Biol Ecol 238:161-184

Caffey HM (1985) Spatial and temporal variation in settlement and recruitment of intertidal barnacles. Ecol Monogr 55:313-332

Cowen RK, Lwiza KMM, Sponaugle S, Paris CB, Olson DB (2000) Connectivity of marine populations: open or closed? Science 287:857-859

Ebert TA, Russell MP (1988) Latitudinal variation in size structure of the west coast [USA] purple sea urchin: a correlation with headlands. Limnol Oceanogr 33:286-294

Forward RB Jr, Tankersley RA, Rittschof D (2001) Cues for metamorphosis of brachyuran crabs: an overview. Am Zool 41:1108-1122

Gaines SD, Bertness MD (1992) Dispersal of juveniles and variable recruitment in sessile marine species. Nature 360: $579-580$

Gaines S, Brown S, Roughgarden J (1985) Spatial variation in larval concentrations as a cause of spatial variation in settlement for the barnacle, Balanus glandula. Oecologia 67: $267-272$

Gaylord B, Gaines SD (2000) Temperature or transport? Range limits in marine species mediated solely by flow. Am Nat 155:769-789

Graham WM, Largier JL (1997) Upwelling shadows as nearshore retention sites: the example of northern Monterey Bay. Cont Shelf Res 17:509-532

Grosberg RK (1982) Intertidal zonation of barnacles: the influence of planktonic zonation of larvae on vertical zonation of adults. Ecology 63:894-899

Hughes TP, Baird AH, Dinsdale EA, Moltschaniwskyj NA, Pratchett MS, Tanner JE, Willis BL (2000) Supply-side ecology works both ways: the link between benthic adults, fecundity, and larval recruits. Ecology 81:2241-2249

Jones GP, Milicich MJ, Emslie MJ, Lunow C (1999) Selfrecruitment in a coral reef fish population. Nature 402: 802-804

Jones GP, Planes S, Thorrold SR (2005) Coral reef fish larvae settle close to home. Curr Biol 15:1314-1318

Kingsford MJ, Leis JM, Shanks A, Lindeman KC, Morgan SG, Pineda J (2002) Sensory environments, larval abilities and local self-recruitment. Bull Mar Sci (Suppl) 70:309-340

Lagos NA, Barria ID, Paolini P (2002) Upwelling ecosystem of northern Chile: integrating benthic ecology and coastal oceanography through remote sensing. In: Castilla JC, Largier JL (eds) The oceanography and ecology of the nearshore and bays in Chile. Ediciones Universidad Catolica de Chile, Santiago, p 117-141

Large WS, Pond S (1981) Open ocean momentum flux measurements in moderate to strong winds. J Phys Oceanogr 11:324-336

Largier JL (2003) Considerations in estimating larval dispersal distances from oceanographic data. Ecol Appl 13: S71-S89

Lough RG (1974) Dynamics of crab larvae (Anomura, Brachyura) off the central Oregon coast, 1969-1971. PhD dissertation, Oregon State University, Corvallis, OR

Lundquist CJ, Botsford LW, Diehl JM, Lee T, Lockwood DR, Morgan LE, Pearson EL (2000) Effects of El Niño and La Niña on local invertebrate settlement in Northern California. CalCOFI Rep 41:1-10

Mace AJ, Morgan SG (in press) Biological and physical coupling in the lee of a small headland: contrasting transport 
mechanisms for crab larvae in an upwelling region. Mar Ecol Prog Ser

Minchinton TE, Scheibling RE (1991) The influence of larval supply and settlement on the population structure of barnacles. Ecology 72:1867-1879

Miron G, Boudreau B, Bourget E (1995) Use of larval supply in benthic ecology: testing correlations between larval supply and larval settlement. Mar Ecol Prog Ser 124:301-305

Miron G, Boudreau B, Bourget E (1999) Intertidal barnacle distribution: a case study using multiple working hypotheses. Mar Ecol Prog Ser 189:205-219

Morgan SG (1995) Life and death in the plankton: larval mortality and adaptation. In: McEdward LR (ed) Ecology of marine invertebrate larvae. CRC Press, Boca Raton, FL, p 279-321

Morgan SG (2001) The larval ecology of marine communities. In: Bertness MD, Gaines, SD, Hay ME (eds) Marine community ecology. Sinauer Associates, Sunderland, MA, p 159-182

Murdoch RC (1989) The effects of a headland eddy on surface macro-zooplankton assemblages north of Otago Peninsula, New Zealand. Estuar Coast Shelf Sci 29:361-384

Paris CB, Cowen RK (2004) Direct evidence of a biophysical retention mechanism for coral reef fish larvae. Limnol Oceanogr 49:1964-1979

Parrish RH, Nelson CS, Bakun A (1981) Transport mechanisms and reproductive success of fishes in the California Current. Biol Oceanogr 1:175-203

Pechenik JA (1987) Environmental influences on larval survival and development. In: Giese AC, Pearse JS (eds) Reproduction of marine invertebrates. Academic Press, New York, p 551-608

Penven P, Roy C, Colin de Verdiere A, Largier J (2000) Simulation of a coastal jet retention process using a barotropic model. Oceanol Acta 23:615-634

Pineda J, Caswell H (1997) Dependence of settlement rate on suitable substrate area. Mar Biol 129:541-548

Rankin KL, Mullineaux LS, Geyer WR (1994) Transport of juvenile gem clams (Gemma gemma) in a headland wake. Estuaries 17:655-667

Rosenfeld LK (1990) Baroclinic semidiurnal tidal currents over the continental-shelf off northern California. J Geophys Res 95:22153-22172

Roughan M, Mace AJ, Largier JL, Morgan SG, Fisher JL, Carter ML (2005a) Subsurface recirculation and larval retention in the lee of a small headland: a variation on the upwelling shadow theme. J Geophys Res: Oceans 110:C10

Roughan M, Terrill EJ, Largier JL, Otero MP (2005b) Observations of divergence and upwelling around Point Loma, California. J Geophys Res: Oceans 110:C4

Roy C (1998) An upwelling-induced retention area off Sene-

Editorial responsibility: Howard I. Browman (Associate Editor-in-Chief), Storebø, Norway gal: a mechanism to link upwelling and retention processes. S Afr J Mar Sci 19:89-98

Shanks AL (1985) Behavioural basis of internal wave-induced shoreward transport of megalopae of the crab Pachygrapsus crassipes. Mar Ecol Prog Ser 24:289-296

Shanks AL (1995) Orientated swimming by megalopae of several eastern North Pacific crab species and its potential role in their onshore migration. J Exp Mar Biol Ecol 186: $1-16$

Shanks AL (2001) An identification guide to the larval marine invertebrates of the Pacific Northwest. Oregon State University Press, Corvallis, OR

Shanks AL, Grantham BA, Carr MH (2003) Propagule dispersal distance and the size and spacing of marine reserves. Ecol Appl 13:S159-S169

Sponaugle S, Cowen RK, Shanks A, Morgan SG and 7 others (2002) Predicting self-recruitment in marine populations: biophysical correlates and mechanisms. Bull Mar Sci (Suppl) 70:341-375

Strathmann MF (1987) Reproduction and development of marine invertebrates of the Northern Pacific Coast. University of Washington Press, Seattle, WA

Strathmann RR, Hughes TR, Kuris AM, Lindeman KC, Morgan SG, Pandolfi JM, Warner RR (2002) Evolution of local recruitment and its consequences for marine populations. Bull Mar Sci (Suppl) 70:377-396

Sulkin SD, McKeen G (1994) Influence of temperature on larval development of four co-occurring species of the brachyuran genus Cancer. Mar Biol 118:593-600

Swearer SE, Shima JS, Hellberg ME, Thorrold SR and 6 others (2002) Evidence of self-recruitment in demersal marine populations. Bull Mar Sci (Suppl) 70:251-271

Warner RR, Swearer SE, Caselle JE (2000) Larval accumulation and retention: implications for the design of marine reserves and essential fish habitat. Bull Mar Sci 66: 821-830

Wing SR, Botsford LW, Largier JL, Morgan LE (1995a) Spatial structure of relaxation events and crab settlement in the northern California upwelling system. Mar Ecol Prog Ser 128:199-211

Wing SR, Largier JL, Botsford LW, Quinn JF (1995b) Settlement and transport of benthic invertebrates in an intermittent upwelling region. Limnol Oceanogr 40:316-329

Wing SR, Botsford LW, Ralston SV, Largier JL (1998) Meroplanktonic distribution and circulation in a coastal retention zone of the northern California upwelling system. Limnol Oceanogr 43:1710-1721

Wing SR, Botsford LW, Morgan LE, Diehl JM, Lundquist CJ (2003) Inter-annual variability in larval supply to populations of three invertebrate taxa in the northern California Current. Estuar Coast Shelf Sci 57:859-872

Submitted: August 29, 2005; Accepted: December 27, 2005 Proofs received from author(s): July 10, 2006 